\title{
THE DEVELOPMENT OF INDEPENDENT LIVING SKILLS IN YOUNG ADULTS WITH INTELLECTUAL DISABILITY IN SHELTERED HOUSING ACCOMMODATION
}

\author{
Rita Raudeliunaite \\ Mykolas Romeris University, Lithuania \\ Vida Gudžinskienè \\ Mykolas Romeris University, Lithuania
}

\begin{abstract}
National Programme for Social Integration of People with Disabilities for 2013 2019 has set a strategic objective to create a positive environment and conditions for a dignified and fully fledged life of people with disabilities in Lithuania, to guarantee equal opportunities and the quality of life of people with disabilities. The article analyses the experiences of the social workers, who work in sheltered housing accommodation with young adults with intellectual disability, when developing independent living skills in young adults with intellectual disability. Sheltered housing accommodation is social services institutions providing social care, in which persons live in home environment and conditions are created for them to manage their own personal life on their own with the support of the social workers. A qualitative-empirical study has been conducted by using the method of a semi-structured interview. The study data were processed by using the method of content analysis. The results of the empirical study are based on the experience of 11 social workers, who have been working in sheltered housing accommodation with young adults with intellectual disability for at least 3 years. The study has revealed that the following independent living skills are considered to be the most easy to be developed: cooking, simple housework, hygiene skills. The young adults also easily develop public transport use skills. The young adults most often acquire work skills by tidying their home environment. The most difficult, according to the social workers, to develop are economic skills: to manage their budget, to allocate finances, to pay for services, and to do the shopping. The young adults with intellectual disability find it difficult to develop their parenting skills. Communication skills are developed while learning etiquette and complying with it in a large range of environments, by encouraging to communicate courteously with other persons, showing personal example, taking a good example from others, taking part in different events, festivals and communal activity. The development of independent living skills occurs by engaging young adults in a practical activity. Particular attention is given to the development of healthy lifestyle skills. The young adults are encouraged to make decisions by guiding them in the right direction, while respecting their interests; the responsibility for the decisions made by them and the consequences of those decisions is also developed. Activity planning, organising and personal skills are developed.
\end{abstract}


Rita Raudeliunaite, Vida Gudžinskiene. The Development of Independent Living Skills in Young Adults with Intellectual Disability in Sheltered Housing Accommodation

Keywords: independent living skills; sheltered housing accommodation; social worker; young adults with intellectual disability.

\section{Introduction}

Article 19 of the United Nations Convention on the Rights of the Persons with Disabilities "Living independently and being included in the community" establishes the right of the persons with disabilities to independent living and comprehensive inclusion in society while distinguishing three key aspects: the country, which has ratified the convention, must give a guarantee that a person with an intellectual disability has the freedom to choose domicile, to receive specialised services, which they need, and to access the services and amenities, which are available in their community, on an equal basis with others. The Convention also establishes the segregation or isolation prevention of the persons with disabilities in the community. European Disability Strategy 2010-2020, Common European Guidelines on the Transition from Institutional to Community Based Care (2012), Lithuanian National Programme on Social Integration of the Persons with Disabilities for 2013-2019, The Action Plan on the Transition from Institutional to Family and Community Based Care for the Persons with Disabilities and Children Deprived of Parental Custody for 2014-2020 also underline the transition from institutional care to community oriented environment, starting with the promotion and support of independent living and ending with houses intended for small groups. L. Rey et al. (2013) maintain that personal independence is considered a person's foundation for quality of life and social integration. The recognition of the autonomy and independence of a person with disabilities marks a shift from social integration as the realisation of the objective of a society's development to social integration as an individual's selfactualisation and self-realisation.

Sheltered housing accommodation for the persons with intellectual disability is a humane alternative to centralised care institutions, which gives the persons with disabilities an opportunity of staying to live in the community and environment they are accustomed to. Sheltered housing accommodation is social service institutions providing social care, in which persons live in home environment and the conditions are fostered for them to independently organise their personal (family) life, partly assisted by a social worker and a social worker's assistant (Social Service Catalogue, 2006).

The young adults with intellectual disability (depending on the level of a disability), living in sheltered housing accomodation, need the greater or lesser assistance of a social worker, which enables them to live independently, to participate and get involved in communities. One of the priority tasks of a social worker is to assist the young adults, who live in sheltered housing accomodation, 
in developing and strengthening independent living skills. The possession of independent living skills strengthens the possibilities of a person with an intellectual disability to independently resolve his social problems, to maintain social ties with society, to participate in society's life, to overcome social exclusion (Fleming, et al., 2016).

Sheltered housing accomodation for the persons with intellectual disability is a new phenomenon in Lithuania, therefore, there is a lack of research in this area. The studies (Germanavičius et al., 2005; Rimšaitè, 2006; Pūras \& Šumskienė, 2012; Pūras et al., 2013; Šumskienè \& Pūras, 2014; Baranauskienè \& Lileikiene, 2015), which analyse the aspects of social care of the persons with intellectual disability, mainly revealed the present condition of these persons in residential care institutions, are creating a demand to develop communal services as an alternative to institutional care.

The studies show that institutional care always cause a lower quality of life and lower quality of services than those provided in the community and often gives rise to social exclusion and segregation for life. According to Samašonok (2013), the process of preparing a person for independent living in care homes is more complicated due to educational system itself when his family is substituted by an institutional authority, in which quite often one-sided and formal work with educatees is performed, they are denied an opportunity to act and resolve their everyday life problems independently, to try out various roles, to draw experience from life, which in its turn does not create favourable conditions for the development and expression of a socially active personality, makes it more difficult to acquire skills which are necessary when living independently.

In the context of the processes of deinstitutionalisation, it is important to analyse the experiences of the provided communal services, including sheltered housing accomodation, for persons with intellectual disability. It is of particular relevance to speak about the development of independence in the young adults with intellectual disability and the possibilities of their social inclusion into the community. The improvement of the preparation of the young adults with disabilities for independent living in the community remains an important and pressing problem facing society.

The objective of the study is to reveal the specificities of the development of independent living skills in the young adults with intellectual disability in sheltered housing accomodation on the basis of the experience of the social workers.

\section{Research methodology}

Research methods. Qualitative research type was chosen for the study. According to J. W. Creswell (2009), the purpose of a qualitative study is to 
research complex phenomena with the properties that are characteristic of them and present the meanings and approaches, that were expressed by the participants of a study, on a researched phenomenon. In the study, the method of a semistructured interview, which enables to come close to the understanding of human experiences, designation of meanings, the definition of meanings and the construction (explanation) of reality, was used. This article overviews the interview questions covered these problematic questions: what independent living skills of the young adults with intellectual disability the social workers, working in sheltered housing accomodation, assist in developing and how they do that.

The obtained data were analyzed by the content analysis method. Qualitative content analysis was carried out in accordance with the inductive, study data based and categories composed logic. According to J. W. Creswell (2009), content analysis is a technique which, having examined the specificities of the text, allows, objectively and systematically, to draw reliable conclusions. The qualitative content analysis was performed regarding the following sequence (Creswell, 2009): repeated reading of the content of transcript interview texts, distinction of meaning elements in the text analysed, grouping of the distinguished meaning elements into categories and sub-categories, integration of the categories/sub-categories into the context of the phenomenon analysed and description of their analysis.

The sample of the research. Criteria-based sample was used in the study. The informants were chosen according to the following criteria: 1) the social workers who have a degree in social work, 2) the social workers who work in sheltered housing accommodation with young adults with intellectual disability; 3 ) the social workers whose length of their working time in sheltered housing accommodation is at least 3 years.

The study was conducted in the October-November of 2016 in sheltered housing accommodation with young adults with intellectual disability. 11 social workers participated in the study.

Ethics of the research. Personal permission of the informants to take part in the research was sought. The researchers obliged themselves to the research participants not to divulge the information related to the organisation and the informant. The principles of anonymity, volunteerism and benevolence were followed. The social workers were acquainted with the goal of the research, the interview questions, and the importance of argumentated reflection on their experience.

The validity of the research: researchers openness for research phenomenon, prejudices and premature suspension of the understanding and reflection. The survey data are interpreted based on critical selfreflection, honesty, careful selection of proving statements. 
The usage of the research results. The findings of the research are important for social workers who work in sheltered housing accommodation with young adults with intellectual disability and for formers of social policy.

\section{Analysis of research results}

The development of independent living skills is one of the most important factors of quality of life assisting the young adults with intellectual disability in integrating into society, in successfully overcoming everyday problems of independent living. The successful development of independence in a person with disabilities depends in a great measure upon independent living skills he possess and upon the fact in what measure the new skills will be linked to the acquired previously.

The scientific researches (Montgomery et al., 2006) revealed that the young adults with intellectual disability, who live independently, often encounter difficulties due to the lack of independent living skills. They need a social worker's assistance, support when developing independent living skills. The objective of the development of independent living skills is to create conditions to each person with intellectual disability, according to their opportunities, to acquire knowledge and skills, which enable to manage their domestic life, to maintain a healthy lifestyle, to eat, to get access to education, to work and the like in the most functional, economic and esthetic manner, i.e. to be as independent of others as possible (Radzevičienè, 2003).

During the study an interest was taken what independent living skills of the young adults with intellectual disability the social workers, working in sheltered housing accomodation, assist in developing and how they do that.

When analysing the findings of the study independent living skills, which the social workers assist in developing in young adults, and the types of assistance used by the social workers, which assist young adults in developing independent living skills, were distinguished (Table 1).

Table 1 The development of independent living skills in the young adults with intellectual disability

\begin{tabular}{|l|l|}
\hline Skills & Types of assistance when developing independent living skills \\
\hline $\begin{array}{l}\text { Household } \\
\text { management }\end{array}$ & $\begin{array}{l}\text { Individual and group counselling, conversations; practical activity on the } \\
\text { advice of a social worker; individual practical tasks; group practical tasks } \\
\text { oriented towards the solution of the problem }\end{array}$ \\
\hline $\begin{array}{l}\text { Personal } \\
\text { hygiene }\end{array}$ & $\begin{array}{l}\text { The creation of favourable emotional atmosphere and positive mutual } \\
\text { relationships in the sheltered housing accomodation; the formation of } \\
\text { appropriate behaviour by setting a good personal example; the discussion }\end{array}$ \\
\hline $\begin{array}{l}\text { Communication } \\
\text { skills }\end{array}$
\end{tabular}




\begin{tabular}{|c|c|}
\hline & $\begin{array}{l}\text { of conduct rules, the adoption of them and adherence to them by common } \\
\text { accord; the organisation of joint festivals and birthdays when encouraging } \\
\text { and developing the friendliness in the young adults, independence, } \\
\text { confidence in their own strength, assistance to each other; by engaging the } \\
\text { young adults in the joint activity of the sheltered housing accomodation } \\
\text { and the community; by accompanying a young adult to other institutions } \\
\text { and authorities, counselling and advising how it is appropriate to behave; } \\
\text { the solving of practical life situations by analysing and solving the } \\
\text { situations or creating educational situations; individual and group } \\
\text { counselling; the discussion of practical situations together with a young } \\
\text { adult while looking for the best way to solve a problem; communication } \\
\text { skills and teaching etiquette; conversations on various communication } \\
\text { topics }\end{array}$ \\
\hline $\begin{array}{l}\text { Healthy } \\
\text { lifestyle }\end{array}$ & $\begin{array}{l}\text { Individual and group counselling; a practical activity which encourages } \\
\text { the young adults to lead a healthy lifestyle; individual and group practical } \\
\text { tasks; conversations }\end{array}$ \\
\hline Economic & $\begin{array}{l}\text { The provision of practical knowledge; the presentation of practical tasks } \\
\text { how to plan monetary income and expenditure, to save, to afford the } \\
\text { housing they are in, to go shopping; individual and group counselling; } \\
\text { advising; demonstration }\end{array}$ \\
\hline $\begin{array}{l}\text { Learning and } \\
\text { labour }\end{array}$ & $\begin{array}{l}\text { Practical activity; conversations when encouraging to obtain professional } \\
\text { training; individual and group counselling; the visitation of vocational } \\
\text { training institutions; assistance when choosing a career which would be in } \\
\text { line a young adult's competences and interests; the provision of emotional } \\
\text { support; assistance when preparing a curriculum vitae, while searching for } \\
\text { information on employment, getting ready for a job interview, while } \\
\text { registering at the employment office; accompanying and mediation; } \\
\text { assistance when overcoming learning difficulties, when solving work } \\
\text { problems }\end{array}$ \\
\hline Personal & $\begin{array}{l}\text { Practical daily activities; individual and group counselling; the provision } \\
\text { of emotional support; the solution of problematic situations }\end{array}$ \\
\hline
\end{tabular}

The results of the study revealed that the social workers assist young adults in developing household management, personal hygiene skills. The informants maintain that each young adult in the sheltered housing accomodation has his own personal space and property, the supervision of which requires from the young adults household management skills and contributes to the development of independence and responsibility. The social workers seek to develop personal responsibility in the young adults for personal hygiene, taking care of their clothes, cleanliness of their room, environment, cooking. It is sought that the young adults, when performing personal hygiene procedures, tidying their home, working in the yard or kitchen, to the extent of their capacities, would do everything independently and would improve the skills they already possess. The informants maintain that the young adults, while carrying out daily chores ,, learn to use household appliances, devices, various kitchen utensils safely“ (A), ,they 
learn to prepare food safely and to keep it safely“ (H), ,to develop washing, ironing, dust cleaning, floor cleaning, carpet vacuum cleaning, waste sorting skills" $(B)$, ", they learn to supervise their personal effects and manage them" (D), "to develop awareness on sanitary, hygiene requirements and come to grips to adhering to them " (I); , they learn to cook and serve food, to lay the table" (C), ", they learn to perform simple clothing repair operations “ $(F)$, ,basic home safety rules are explained and how to behave in case of danger, who to contact for urgent assistance in special cases " $(K)$.

The social workers maintained that when enhancing household management and personal hygiene skills in the young adults it is important to follow the principles of an individual approach, systematicity, continuity and transferability. The informants pointed out that when assisting the young adults in developing the mentioned skills they counseled them individully and in small groups, the young adults performed group practical tasks oriented towards the solution of the problem, developed skills individually and during group practical workshops, for example, lunch cooking together with the young adults at weekends and on public holidays.

The informants noted that, for the young adults, cooking, housework, hygiene, environment tidying and public transport use skills are easiest to develop.

Having analysed the findings of the study, it can be said that the informants attach great importance to the development of communication skills in the young adults with intellectual disability. The social workers seek that, in the sheltered housing accomodation, positive mutual relationships, favourable emotional atmosphere would be created when strengthening humane relationships, which are based on respect and trust, among the young adults themselves and between the social workers, their assistants and the young adults. The informants maintained that the employees, when communicating with the young adults, attempt to behave positively, to demonstrate the example of an appropriate communication. The young adults also discuss and adopt the rules, which regulate mutual relationships and facilitate communication,

together by common accord, the rules, which each agrees to follow and adhere to. Positive mutual relationships are also sought to be created by organising joint festivals, birthdays, encouraging and developing friendliness, independence, confidence in their own strength, assistance to each other in the young adults.

Communication skills are developed in the young adults by engaging them in a joint activity: community festivals, voluntary service, events, excursions etc. By participating in the various events, the young adults have an opportunity to develop communication skills when communicating with other people, they learn to be among strangers, they expand and enrich their social relationships and develop a socially appropriate behaviour. It should be noted that social skills are built up during a person's active engagement. Practical activity assists in realising 
Rita Raudeliunaite, Vida Gudžinskiene. The Development of Independent Living Skills in Young Adults with Intellectual Disability in Sheltered Housing Accommodation

the skills, which have already been built up, and strenthening them by practical experience.

Communication skills are developed also by accompanying a young adult to other institutions and authorities. The informants noted that, although a social worker is at hand, a young adult is always encouraged to talk independently, to request the assistance, to manage their own personal affairs: ,, by accomponying a young adult to institutions, authorities, we teach how to behave, how to get where they need, what to say " $(G)$.

According to the informants, a personal social worker's example contributes towards the development of appropriate communication skills most: "...I always explain, set an example of courteous communication"(I), "you show that you need to communicate corteously, not to scream, not to shout, to tell what you want calmly and clearly" (D). Communication skills are also developed and established by taking part in the solving of practical life situations, the analysis and solution of the situations, which have emerged, or creating educational situations: "if somebody behaved inappropriately, we ask how he feels when communicating inappropriately (shouting, screaming), whether he would like to take the place of the person he shouted at" (E); ,we sit down and perform the situation, we teach how they need to behave, to communicate and we tell how they should not behave" (K); "if some conflict situation emerges and somebody curses and uses swear words, after that, counselling always follows “ $(C)$, ,,during the counselling, most frequently we simply encourage a young adult to express his opinion, to think over calmly, not to be in a hurry " $(B)$. When counselling a young adult his personal opinion is always heard, later on, when discussing practical situations together with a young adult, the best approach to the problem is sought.

The informants maintained that it is particularly important to teach a young adult to be open, to dare to request assistance when it is necessary: ,we strongly encourage our clients to dare to request the employees or other people for assistance, if the situation is not clear or they do not understand anything " $(F)$.

During practical workshops, bullying and reactions are discussed: ,not only did we encourage not to bully, but to be active themselves, if they notice bullying" (B), ,we discuss the causes of bullying and its consequences, tolerance, on the basis of real life situations from their own, other people's experience" $(C)$. The social workers maintained that they invest considerable time in joint conversations: ,we talk a lot about feelings. We react, if we see bullying in the mutual relationships of the residents " $(H)$. The informants maintain that they teach the young adults not to be afraid to corteously express their opinion and cheer up the shier young adults: ,we always emphasise to the shy young adults that they would express their opinion in any case, even if it completely contradicts that of the employees or other people, however, that they would do that courteously" $(G)$. The social workers maintained that they inform the young 
adults on the human rights: ,we talk on the human rights, we inform, we simply analyse situations when some situation emerges to the client himself, we analyse the actions of other people, we talk about what it is possible to do and what has not been done and the like " $(C)$. The young adults with intellectual disability can be bullied because of their disability, it is particularly important that they would distinguish bullying, would observe how they behave themselves, would learn to understand wheher they really do not hurt others by their actions and words.

A large degree of importance is attached to the development of healthy lifestyle skills in the young adults. The social workers encourage the young adults to look after their health, to build up healthy lifestyle skills. During the study, the informants revealed that they often counsel the young adults on healthy lifestyle, they accustom them to maintain a healthy lifestyle: ,, we encourage daily physical activity, to get rid of harmful habits" (A), "we accustom them to spend their leisure time meaningfully and actively" (D), ,they learn to cook a healthy and valuable food" $(K)$, ,, we strengthen the emotional health of the young adults by teaching them to resolve conflicts, to adequately respond to remarks and various calming down and self-control techniques " $(G)$.

The social workers have particular regard to the development of the economic skills in the young adults with intellectual disability. The informants noted that, when developing economic skills, practical knowledge and practical experience, which many of the young adults, who have come to reside in sheltered housing accomodation, do not have, are of particular importance. Therefore, when developing the economic skills in the young adults it is sought that they would acquire practical knowledge and practical experience. The social workers pointed out that the young adults, with their assistance, learn to plan monetary income and expenditure, learn to save, to afford the housing they are in, to go shopping: , they learn to create a plan what for, when and what sum will be used" (A) ,, what sum they can lay aside from the income they receive" $(G)$, ,they learn to save" $(K)$ ",together with young adults, we go to the shopping centres, we show how they have to go shopping, we advice which goods are of higher quality, which price is the most acceptable, we teach to use an automatic teller machine in order that he would be able to withdraw money for himself, that he would be able to check his account balance, in order that he would see and know himself how much he has got for subsistence" $(F)$. The informants noted that when developing the economic skills of the young adults they assist, teach and advice them, however, they always follow the rule to encourage the young adults to be independent, to learn to do everything on their own and not to do it instead of them. On the other hand, the informants pointed out that economic skills are the most difficult to develop.

The informants noted that it is particularly important for the young adults with intellectual disability to obtain proper education, to find a job, to express 
Rita Raudeliunaite, Vida Gudžinskiene. The Development of Independent Living Skills in Young Adults with Intellectual Disability in Sheltered Housing Accommodation

themselves, to develop independence, to integrate into society. Therefore, the social workers attach great importance for the development of the learning and labour skills in the young adults. Having analysed the findings of the study, it was revealed that the social workers develop the labour skills of the young adults with intellectual disability through practical activities. The young adults most often acquire labour skills by tidying their home environment, performing their housework chores: „,...we go out to rake leaves together, to sweep the yard, we plant flower beds " (I), "...extensive work is necessary, you need to weed up, you need to water, to plant..." $(K)$. The informants maintain that the young adults are encouraged to obtain professional training in order that they would be able to more successfully integrate into labour market: ,you encourage to take up vocational education, to obtain a trade " $(C)$, ,we visit vocational training establishments " $(E)$, ,, together with an adolescent, we discuss and assist in choosing the career which would be in line with his competences and interests" $(F)$, „I provide emotional support to the young adults who learn or work" $(G)$. The social workers also assist a young adult both in integrating into labour market and while registering at the employment office and when communicating with potential employers, while preparing a curriculum vitae for the young adults, getting ready for a job interview: ,if anybody needs, we register all such people at the employment office, if, for example, they need to communicate with their workplace, then we also communicate" (D); ,we assist in seeking employment, we help him prepare a curriculum vitae, we go for a job interview together, we accompany to work on their first workday and encourage him, we explain and mediate, in order that a young adult would be able to adapt easier " $(B) ;$;, together with young adults, we look for job advertisements, we accompany to their job interview" $(J)$. It should be noted that a part of the young adults with intellectual disability get successfully established in the labour market: ,there are working residents, it can be established that we have persons who got established in the labour market" (B). The social workers asserted that their assistance in expanding young adults" learning and labour skills is support, counselling, help when overcoming personal, learning, work problems.

The development of personal skills is one of the important factors of successful social integration of the young adults with intellectual disability. The social workers assist young adults in developing self-knowledge, self-control, coping with stress, conflict resolution, decision-making, self-trust, personal responsibility, dutifulness skills: ,for a young adult, it is particularly important to know himself, therefore, we pay great attention to self-knowledge, to reveal and to develop self-trust" (A), "self-control is very important, in order that the young adults would be able to get established in society and not to get into conflict in the community" (E), ,, self-control is significant in order to maintain working relationships, to communicate properly" $(K)$, "we develop dutifulness and 
responsibility through the establishment of rules and adherence to them in daily life" $(C)$. The young adults are assisted in acquiring personal skills by the provision of individual and group counselling, the teaching how to resolve problematic situations, conflicts, the provision of emotional support to them.

\section{Conclusions}

On the basis of the experience of the social workers it was revealed that the social workers, when preparing the young adults with intellectual disability for independent living, pay particular attention to the development of communication, personal hygiene, healthy lifestyle, housekeeping, economic, labour and personal skills. The study revealed that the young adults with intellectual disability find it easiest to build up cooking, domestic work, personal hygiene, environment tidying and public transport use skills. The hardest, for the young adults with intellectual disability, to develop are economic and parenting skills.

The social workers assist the young adults with intellectual disability, who live in the sheltered housing accomodation, in developing independent living skills in them in the following ways: individual and group counselling, conversations, practical activity, individual and group practical tasks oriented towards the solution of a problem, solving practical life situations, analysing and solving situations which have emerged or creating educational situations, the provision of practical knowledge, demonstration, discussing of practical situations together with a young adult when searching for the best way to solve a problem, advising, assistance, the creation of a favourable emotional atmosphere and positive mutual relationships in the sheltered housing accomodation, the provision of emotional support, a personal example, the establishment of behaviour rules and adherence to them, teaching etiquette, the accompanying of a young adult and mediation.

\section{References}

Baranauskienè, I., \& Lileikienè, A. (2015). The strategies of coping with the difficulties of young people with mental disorders, who have left institutional care for children and youth. Society. Integration. Education. Proceedings of the International Scientific Conference, 2, 20-30.

Creswell, J. W. (2009). Research Design: Qualitative, Quantitative, and Mixed Methods Approaches. 3 rd Edition. Los Angeles: Sage Publications.

Common European Guidelines on the Transition from Institutional to Community Based Care. (2012). Downloaded from http://deinstitutionalisationguide.eu/

European Disability Strategy 2010-2020. Downloaded from http://eur-lex.europa.eu/ LexUriServ/LexUriServ.do?uri=COM:2010:0636:FIN:en:PDF 
Rita Raudeliunaite, Vida Gudžinskiene. The Development of Independent Living Skills in Young Adults with Intellectual Disability in Sheltered Housing Accommodation

Fleming, P., McGilloway, S., \& Barry, S. (2016). The successes and challenges of implementing individualised funding and supports for disabled people: an Irish perspective. Disability \& Society, 1-16.

Germanavičius, A., Pūras, D., Šakalienè, D., Rimšaite, E., Mališauskaite, L., \& Povilaitis, R. (2005). Žmogaus teisiu stebèsena uždarose psichikos sveikatos priežiūros ir globos institucijose. Vilnius: Žmogaus teisių stebejjimo institutas, Globali iniciatyva psichiatrijoje, Lietuvos sutrikusio intelekto žmonių globos bendrija „Viltis“, Vilniaus psichosocialinès reabilitacijos centras.

Lietuvos Respublikos socialinès apsaugos ir darbo ministro $2006 \mathrm{~m}$. balandžio $5 \mathrm{~d}$. įsakymas Nr. A1-93. Socialiniu paslaugu katalogas. Downloaded from https://e-seimas.lrs.lt/ portal/legalAct/lt/TAD/TAIS.274453

Lietuvos Respublikos socialinès apsaugos ir darbo ministro $2014 \mathrm{~m}$. vasario $14 \mathrm{~d}$. Issakymas Nr. A1-83. Perëjimo nuo institucinès globos prie šeimoje ir bendruomenèje teikiamu paslaugu neigaliesiems ir likusiems be tèvu globos vaikams 2014-2020 metu veiksmu planas. (2014). Downloaded from https://www.e-tar.lt/portal/lt/legalAct/c90d41f097 de11e3bdd0a9c9ad8ce1bf

Montgomery, P., Donkoh, C., \& Underhill, K. (2006). Independent living programs for young people leaving the care system: The state of the evidence. Children and Youth Services Review, 28 (12), 1435-1448.

Nacionalinė neiggaliųų socialinès integracijos 2013-2019 programa. Downloaded from https://e-seimas.lrs.lt/portal/legalAct/lt/TAD/TAIS.437985

Pūras, D., \& Šumskiené, E. (2012). Psichikos negalią turinčių asmenų globa Lietuvoje: priklausomybè nuo paveldètos paslaugų teikimo kultūros. Social Theory, Empirics, Policy and Practice, 6, 87-96.

Pūras, D., Šumskienè, E., \& Adomaitytė-Subačienè, I. (2013). Challenges of prolonged transition from totalitarian system to liberal democracy, Journal of Social Policy and Social Work in Transition, 3 (2), 31-54.

Radzevičienè, L. (2003) Vaiku, turinčiu specialiuju poreikiu, psichosocialinè raida. Šiauliai: Šiaulių universiteto leidykla.

Rey, L., Extremera, N., Durán, A., \& Ortiz-Tallo, M. (2013). Subjective Quality of Life of People with Intellectual Disabilities: The Role of Emotional Competence on Their Subjective Well-Being. Journal of Applied Research in Intellectual Disabilities, 26 (2), 146-156.

Rimšaitė, E. (2006). Psichoneurologiniai pensionatai: socialinio darbo ar disciplinarinès visuomenès institutas? Sociologija. Mintis ir veiksmas, 131-139

Samašonok, K. (2013). Globos namuose gyvenančių children ir paauglių savarankiško gyvenimo ịūdžių ugdymas: pasiekimai, sunkumai, sprendimai. Pedagogika, 110, 103114.

Šumskienè, E., \& Pūras, D. (2014). Eikit pažiūrèt, kaip neturi būt: psichikos sveikatos politikos raida ir jos rezultatai, Socialinis darbas. Patirtis ir metodai, 13 (1), 75-90. 